\title{
The Impacts of Product Packaging Elements on Brand Image and Purchase Intention - An Empirical Study of Phuc Long's Packaged Tea Products
}

\author{
Mai Ngoc Khuong and Nguyen Thi Huyen Tran
}

\begin{abstract}
This research aimed to examine the effects of product packaging on purchase intention through the mediating role of brand image, with the example of Phuc Long's packaged tea products. Quantitative approach is applied with the sample size of 410 consumers living in Ho Chi Minh City (HCMC), Vietnam. The results showed that packaging font, picture, shape and color have direct and indirect associations with purchase intention whereas product information, ease of use and handle have indirect ones. However, material and size do not have any influences. Suggestions are given to develop a differentiated packaged for tea products by: (1) using eye-catching pictures and (2) vivid colors, (3) designing a good packaging shape, (4) carefully choosing the amount of product information, and (5) designing an easy-handling, or -opening and -closing, or -disposing package.
\end{abstract}

Index Terms-Brand image, packaging design, product packaging, purchase intention.

\section{INTRODUCTION}

In current marketplace, it is estimated that consumers spend no more than one minute to scan for and decide to buy the products they need [1]. Hence, constantly improving product packaging is believed to be one of the most feasible approach that businesses can do to gain consumers' attention. Product packaging is considered as a "sales promotional tool for the organizations" [2]. An appealing and differentiated package can help a product to stand out among other similar items [3] and thus, it acts as a vital factor in stimulating purchase intention [2], [4]. Furthermore, product packaging also helps to shape the brand image in consumers' mind [5].

Besides, tea is a healthy and traditional beverage, representing the communication culture of Vietnam. Although Vietnam is one of the largest exporters in tea sector, the value of tea products is so low. One of the reasons are weak brand positioning in marketplace [6]. Additionally, in HCMC, Phuc Long with the model of tea and coffee shop has been one of the most well-known brand since 2013 and it was ranked the third in the list of brand recognition [7]. In recent years, although most Phuc Long's customers prefer to buy take-away drinks such as milk tea, cappuccino, blended beverages, etc., a wide variety of packaged tea products are still purchased regularly.

Manuscript received October 15, 2017; revised January 3, 2018.

Mai Ngoc Khuong and Nguyen Thi Huyen Tran are with the School of Business Administration, International University, Vietnam National University Ho Chi Minh City, Vietnam (e-mail: mnkhuong@hcmiu.edu.vn, trannguyennth@gmail.com).

\section{LITERATURE REVIEW}

\section{A. Product Packaging Elements}

Product packaging plays as an integral role for conveying the brand message to its target customers [8] and the knowledge about the commodity. "A good packaging is far more than a salesman, it is a flag of recognition and a symbol of values" [9]. In this research, product packaging combines: visual (color, picture, font, shape and size), informational factor (packaging material and product information) [10], and package-ease of use and -ease of handle [11].

Packaging color increases brand identification and widens visual difference [12]. Besides, it emphasizes, generates emotional responses and intensifies memorability of consumers about a certain product. About 62 to 90 percent of people usually consider a product based on only its packaging color [13].

Packaging picture helps to grasp consumers' attention and plays as an informational input to compare and differentiate a brand over others [14]. Nearly a half of consumers claimed that they use pictures as an indication of product quality [15].

Since packaging font is a mean of communication between producers and consumers, companies who have much experience on this element are more successful than ones who do not [10]. Particularly, a font style which is small and dense in writing can result in misunderstanding and inaccurate information for consumers [4].

Packaging shape is an ideal indication of the product's volume [16] and it also delivers the competitive advantages of that brand [17]. No matter what the design of the shape is, manufacturers should ensure that it can bring the product arrive in a good condition and in a form of a package that can attract consumers [18].

Products with the large package are usually consumed more than items with the small one [19] because consumers believe the unit cost of those products is much smaller than, and they also less concern about running out of the product [20]. Therefore, a product being of various sizes influences consumer purchase intention more significantly [21] than an item which is of only one size.

Product information printed on the package helps to compare quality and value of a certain product to other similar items [4]. They are usually about quantity, instructions for using, ingredients, name of manufacturers and retail stores, and target consumers, etc. Besides, although product information can "reduce the uncertainty and enhance product credibility", it also can make consumers confused if there is too much or misleading and inaccurate information [22]. 
Packaging material plays as an important role in preventing product from losses [23]. Besides, it also helps to protect the product from moisture, heat, dust, etc. [24]. Moreover, products packaged in glass material, which is evaluated as an environmentally friendly material [25], look high-quality while ones packaged in folding boxed cartons look cheap [26].

Generally, packaged-ease of use is defined as the degree to which a consumer believes that using a particular product would be free of effort [27]. Particularly, consumers can use that product without the need for an advanced explanation or instruction manual.

Package-ease of handle is defined as the extent to which consumers can store or handle products and prevent them from damage or breakage. In [11], it is concluded that this dimension does not have any significant associations with purchase intention under any types of consumer experience. However, when consumers are able to touch or use the product, it is more important [11].

\section{B. Brand Image}

Brand image refers to the extent to how consumers associate to a particular brand [28]. In other words, it is about how consumers think and feel about that brand [29] and it includes a set of attributes which are significant to consumers [30]. Brand image is very important since it helps to position the brand in the market [31]. Furthermore, on the basis of brand image, consumers can process the information of a certain brand and then differentiate it with others [30], and they also can recognize their needs and satisfactions towards that brand [32]. A good brand image can stimulate consumer purchase intention and increase the brand's value [32]. The brand with a strong image will have more competitive advantages over their rivalries [33].

\section{Consumer Purchase Intention}

Purchase intention is defined as consumers' feelings, thoughts, experience and other external factors that they take into account before purchasing a specific product or service [34]. In other words, it represents to what consumers think they may and will buy [35] and the degree to how satisfactory a product or service meets the consumers' demand [36]. Besides, consumer buying behavior can be observed from two different perspectives: (1) what products consumers think about and (2) where consumers tend to buy that item [37]. In the case of where consumers make these decisions independently, what to buy versus where to buy, informational factors of product packaging tend to be more important than visual ones. Moreover, for consumers who decide to buy a good without planning before, extrinsic attributes of the product packaging are heavily essential [15]. Package-ease of use and handle also significantly influence consumer purchase intention [11].

\section{Conceptual Framework Development}

To sum up, the conceptual framework of the research is built based on the study of [4], [5], [10], and [11] with three main hypotheses:

H1: Product Packaging Elements positively affect Brand Image.

H2: Product Packaging Elements and Brand Image positively affect Consumer Purchase Intention.

H3: The effect of Product Packaging Elements on Consumer Purchase Intention is mediated by Brand Image.

\section{METHODOLOGY}

\section{A. Research Design and Data Collection}

Quantitative approach is applied. Target population is consumers living in HCMC no matter if they have known about Phuc Long or bought its products or not. The sample size is 410 respondents. In terms of data analysis technique, SPSS is mainly used to provide information of descriptive analysis, reliability test, exploratory factor analysis, multiple regression, and path analysis.

Regarding questionnaire, 45 items are adapted from numerous authors to measure the extent of brand image, purchase intention and product packaging elements. They are rated by the five-point Likert scale ( $1=$ strongly disagree, $5=$ strongly agree). Besides, five questions related to respondents' profile are also included. The questionnaire is delivered in two forms: online and offline self-administered survey.

\section{B. Factor Analysis and Reliability}

For the group of independent variables, the research initially proposed nine elements of product packaging. However, questions related to Packaging Size (PASIZE) ( $\alpha=$ 0.646) is removed because the value of Cronbach's Alpha does not meet the requirement of larger than 0.70 [38] Besides, five measurement items are also deleted to increase the value of Cronbach's Alpha. After that, the remaining independent variables are combined into five groups: (1) Color, (2) Picture, Font and Shape, (3) Product Information, (4) Material, (5) Ease of Use and Handle.

TABLE I: SUMMARY OF INDEPENDENT VARIABLES $(N=410)$

\begin{tabular}{lcc}
\hline \hline \multicolumn{1}{c}{ Variable } & $\begin{array}{c}\text { Number of } \\
\text { items }\end{array}$ & $\begin{array}{c}\text { Cronbach's } \\
\text { Alpha }\end{array}$ \\
\hline Color (PACOLO) & 4 & .775 \\
Picture, Font \& Shape (PAFOPISH) & 7 & .844 \\
Product Information (PAINFO) & 3 & .862 \\
Material (PAMATE) & 4 & .810 \\
Ease of Use and Handle (PAEOUNOH) & 6 & .918 \\
\hline \hline
\end{tabular}

Particularly, the eigenvalues of theses groups are larger than 1 , accounting for $65.429 \%$ of the total variance. KMO is 0.933 [39], indicating the suitability of dataset to conduct principal component analysis, and the value of Bartlett's Test is 0.000 [40], showing the sufficient correlation among variables for further tests. Additionally, Cronbach's Alpha ranges from 0.775 to 0.918 , displaying high reliability (Table I).

TABLE II: SUMMARY OF DEPENDENT VARIABLES $(N=410)$

\begin{tabular}{lcc}
\hline \hline \multicolumn{1}{c}{ Variable } & $\begin{array}{c}\text { Number of } \\
\text { items }\end{array}$ & $\begin{array}{c}\text { Cronbach's } \\
\text { Alpha }\end{array}$ \\
\hline Purchase Intention (PURINT) & 5 & .784 \\
Brand Image (BRANIMAG) & 5 & .832 \\
\hline \hline
\end{tabular}

Similarly, two questions measuring PURINT and BRIMAG are deleted to increase the value of Cronbach's Alpha to 0.784 and 0.832 , respectively (Table II). These two 
dependent variables reflect $57.1113 \%$ of the total variance, with the KMO of 0.825 and the value of Bartlett's Test of 0.000 .

\section{RESEARCH FINDINGS}

\section{A. Demographic Characteristics of Respondents}

TABLE III: DEMOGRAPHIC CHARACTERISTICS OF RESPONDENTS $(N=410)$

\begin{tabular}{lrr}
\hline \hline & $\begin{array}{r}\text { Frequency } \\
(\boldsymbol{n})\end{array}$ & $\begin{array}{r}\text { Percentage } \\
(\boldsymbol{\%})\end{array}$ \\
\hline 1. Gender & 151 & 36.8 \\
Male & 259 & 63.2 \\
Female & 351 & \\
\hline 2. Have you ever bought any tea products? & 55.6 \\
Yes, I have bought before & 59 & 14.4 \\
$\quad$ No, I have not bought before & 387 & \\
\hline 3. Do you like drinks made by tea? & 23 & 54.4 \\
Yes & 5.6 \\
No & 401 & \\
\hline 4. Have you known about Phuc Long Coffee and Tea brand? & \\
Yes, I have known before & 97.8 \\
No, I have not known before & 2.2 \\
\hline 5. Have you ever bought any products of Phuc Long & \\
Coffee and Tea brand? & & \\
Take-away products & 213 & 52.0 \\
Packaged products & 23 & 5.6 \\
I have bought both take-away and & 147 & 35.9 \\
packaged products & & \\
I have not bought any products of & & \\
this brand & 27 & 6.5 \\
\hline \hline
\end{tabular}

Table III illustrates the profile of 410 respondents living in HCMC. The number of female respondents nearly doubles that of male ( $63.2 \%$ compared with $36.8 \%$ ). Additionally, the majority have bought tea products and also favor it, at $85.6 \%$ and $94.4 \%$ of the total, respectively. Surprisingly, Phuc Long brand is quite famous since up to 401 respondents knew about it. Regarding products, whereas more than half of the participants have bought take-away products, packaged items were purchased by only $5.6 \%$ of respondents. Besides, $35.9 \%$ of respondents said that they have bought both of them. Lastly, $6.5 \%$ of the respondents have not bought any Phuc Long's products.

\section{B. Correlations between Variables}

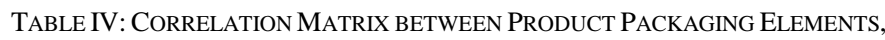
BRAND IMAGE AND PURCHASE INTENTION

\begin{tabular}{lccccccc}
\hline \hline & PURINT & 1 & 2 & 3 & 4 & 5 & 6 \\
\hline 1. PAEOUNOH & .278 & & & & & & \\
2. PAFOPISH & .376 & .541 & & & & & \\
3. PAINFO & .308 & .661 & .461 & & & & \\
4. PACOLO & .375 & .515 & .577 & .473 & & & \\
5. PAMATE & .303 & .634 & .516 & .596 & .471 & & \\
6. BRIMAG & .395 & .440 & .457 & .415 & .459 & .363 & \\
\hline \multicolumn{1}{c}{ Mean } & 3.266 & 4.009 & 3.705 & 3.951 & 3.669 & 3.790 & 3.731 \\
\multicolumn{1}{c}{ SD } & .6913 & .6730 & .6248 & .7512 & .6907 & .7011 & .6134 \\
\hline \hline
\end{tabular}

From Table IV, PURINT correlates significantly and positively to the other variables in the research: BRIMAG $(r=$ 0.395), PAFOPISH $(r=0.376)$, PACOLO $(r=0.375)$, PAINFO $(r=0.308)$, PAMATE $(r=0.303)$ and PAEOUNOH $(r=0.278)$. In other words, an increase in the percentage of the usage of every product packaging element or in the perception of brand image leads to an increase in purchase intention. Besides, PAEOUNOH, PAFOPISH, PAINFO, PACOLO, and PAMATE also have a positive association with BRIMAG, at $r=0.440, r=0.457, r=0.415$, $r=0.459, r=0.363$ respectively. It indicates the higher percentage of the usage of every product packaging element, the higher perception of brand image in consumers' mind.

\section{Testing Hypotheses}

Firstly, two multiple regression analyses are conducted to find the direct effects between Product Packaging Elements on Brand Image and Purchase Intention, which is the hypothesis $\mathrm{H} 1$ and $\mathrm{H} 2$. After that, $\mathrm{H} 3$ is examined by the bootstrapping method [41]. Particularly, the absence of the number zero between the lower (LLCI) and upper (ULCI) boundary of the confidence interval indicates a significantly indirect effect and vice versa.

\section{1) Factors directly affecting brand image (HI)}

TABLE V: COEFFICIENTS OF BRAND IMAGE (BRIMAG)

\begin{tabular}{lccc}
\hline \hline & $\begin{array}{c}\text { Unstandardized } \\
\text { Coefficients }(\boldsymbol{\beta})\end{array}$ & $\mathbf{t}$ & Sig. \\
\hline (Constant) & 1.385 & 7.591 & .000 \\
PAEOUNOH & .125 & 2.176 & .030 \\
PAFOPISH & .199 & 3.658 & .000 \\
PAINFO & .112 & 2.342 & .020 \\
PACOLO & .187 & 3.891 & .000 \\
PAMATE & -.009 & -.173 & .863 \\
\hline \hline
\end{tabular}

a. Dependent Variable: BRIMAG: Brand Image

b. Predictors: (Constant), PAMATE: Packaging Material, PACOLO: Packaging Color, PAINFO: Packaging Information, PAFOPISH: Packaging Font, Picture and Shape, PAEOUNOH: Package Ease of Use and Handle

c. ANOVA: $\mathrm{F}(5,404)=35.117$, Sig. $=.000, p<.05$

d. Model summary: R Square $=.303$

From Table V, PAMATE has the significance value of $p=$ $0.863>0.05$, indicating that there is no association between PAMATE and BRIMAG. Meanwhile, with the significance value of $p$ less than 0.05 , PAEOUNOH, PAFOPISH, PAINFO, and PACOLO positively affect BRIMAG, with the $\beta$-value of $0.125,0.199,0.112$ and 0.187 respectively. These factors of product packaging reflect $30.3 \%$ of the total variance of brand image.

2) Factors directly affecting purchase intention (H2)

TABLE VI: COEFFICIENTS OF PURCHASE INTENTION (PURINT)

\begin{tabular}{lccc}
\hline \hline & $\begin{array}{c}\text { Unstandardized } \\
\text { Coefficients ( } \beta)\end{array}$ & $\mathbf{t}$ & Sig. \\
\hline (Constant) & .893 & 3.858 & .000 \\
PAEOUNOH & -.088 & -1.290 & .198 \\
PAFOPISH & .170 & 2.592 & .010 \\
PAINFO & .075 & 1.302 & .194 \\
PACOLO & .149 & 2.575 & .010 \\
PAMATE & .074 & 1.228 & .220 \\
BRIMAG & .263 & 4.454 & .000 \\
\hline \hline
\end{tabular}

a. Dependent Variable: PURINT: Purchase Intention

b. Predictors: (Constant), BRIMAG: Brand Image, PAMATE: Packaging Material, PACOLO: Packaging Color, PAINFO: Packaging Information, PAFOPISH: Packaging Font, Picture and Shape, PAEOUNOH: Package Ease of Use and Handle

c. ANOVA: $F(6,403)=20.028$, Sig. $=.000, p<.05$

d. Model summary: R Square $=.230$

PAEOUNOH, PAINFO, PAMATE has the p-value of $0.198,0.194$, and 0.220 respectively, indicating no direct effects between these variables and PURINT (Table VI). 
However, the significance value of the other variables is less than 0.05. Particularly, PAFOPISH, PACOLO and BRIMAG has direct associations with PURINT, at the $\beta$-value of 0.170 , 0.149 , and 0.263 respectively. These components of product packaging and brand image together contribute $23.0 \%$ of the total variance of purchase intention.

3) Indirect effects of product packaging elements on purchase intention through the mediating role of brand image (H3)

Based on the bootstrapping method [41], PAEOUNOH, PAFOPISH, PAINFO, and PACOLO are found to have the indirect effects on PURINT through the mediating role of BRIMAG, at $0.0329,0.0523,0.0296$ and 0.0491 respectively. However, PAMATE does not because there is a number zero falling between LLCI and ULCI (Table VII).

\section{4) Path Analysis and Total Causal Effects}

In short, PAFOPISH and PACOLO influence directly and also indirectly PURINT through the mediating role of BRIMAG. The remaining independent variables PAEOUNOH and PAINFO only have indirect effects. Also worth noticing is that PAMATE does not have any associations and items measuring PASIZE are not reliable enough. Besides, BRIMAG also directly affects PURINT. These findings are illustrated in the path diagram (Fig. 1).

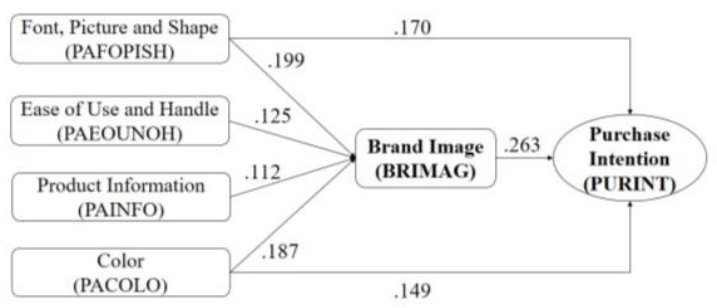

Fig. 1. Path diagram.

Besides, based on the rule of [41], the calculation of direct, indirect and total causal effects are shown in Table VII. Particularly, the total effect of PAINFO $(\beta=0.0296)$, or PAEOUNOH $(\beta=0.0329)$ on PURINT is trivial while that of PACOLO $(\beta=0.1981)$, or PAFOPISH $(\beta=0.2223)$, or BRIMAG $(\beta=0.2630)$ is low to moderate. However, the effect of the whole independent variables (PAEOUNOH, PAFOPISH, PAINFO and PACOLO) on PURINT through the mediating role of BRIMAG is 0.7459 , indicating a very strong relationship [42].

TABLE VII: DIRECT, INDIRECT AND TOTAL CAUSAL EFFECTS

\begin{tabular}{lrrrrr}
\hline \multirow{2}{*}{ Variable } & \multicolumn{3}{c}{ Causal Effects } & \multirow{2}{*}{ LLCI } & \multirow{2}{*}{ ULCI } \\
\cline { 2 - 4 } & Direct & Indirect & Total & & \\
\hline PAEOUNOH & --- & .0329 & .0329 & .0070 & .0636 \\
PAFOPISH & .170 & .0523 & .2223 & .0246 & .0857 \\
PAINFO & --- & .0296 & .0296 & .0077 & .0545 \\
PACOLO & .149 & .0491 & .1981 & .0235 & .0791 \\
BRIMAG & .263 & --- & .2630 & ---- & ---- \\
\hline \multicolumn{1}{c}{ Total } & .582 & 0.1639 & .7459 & & \\
\hline \hline
\end{tabular}

\section{DISCUSSION, LIMITATION AND RECOMMENDATION}

\section{A. Discussion of the Findings}

BRIMAG has the highest total causal effect on PURINT ( $\beta$ $=0.2630$ ) (Table VII). The better image the brand owns, the higher intention consumers want to engage in that brand. As a result, it can significantly increase the brand's revenue. Additionally, brand image is a good mediation role between product packaging elements and purchase intention. Especially, the factors of product packaging are PAEOUNOH $(\beta=0.0329)$; PAFOPISH $(\beta=0.0523)$; PAINFO $(\beta=0.0296)$; and PACOLO $(\beta=0.0491)$ (Table VII). These results support the study of [5].

In terms of direct effects, with the $\beta$-value of 0.170 (Table VII), PAFOPISH is the second most influential factor to PURINT. It can be concluded that packaging pictures which are easy to remember, or notice and identify can increase consumer purchase intention. Similarly, if company chooses the font which is readable from distance, or easy to remember, consumers are more willing to buy products of that company. Packaging shape which is easy to remember, or find in stores also results in higher consumer purchase intention. Moreover, PACOLO $(\beta=0.149)$ also has a significant relationship with PURINT (Table VII). Consumers are more likely to prefer the colorful package, especially which helps them remember easily, draws their attention or differentiates the package with others. These results are similar with that of [4] and [10].

Furthermore, time pressure and the level of involvement of the product are not analyzed in this study compared with that of [10]. Besides, no findings are found to support the relationship between PASIZE and PURINT while [10] concluded the existence of this relationship. This may due to the difference in the example of product: between food and beverage products.

Moreover, the result of this research pointed out a new factor acting as a mediation role in the relationship between product packaging elements and purchase intention to the study of [4]. That is brand image. Besides, it is concluded that PAINFO directly affects PURINT [4], but this variable only has indirect relationship with PURINT in this study. There is also no statistic results proving the relationship between PAMATE and PURINT in this research compared with that of [4]. The reason to explain these differences may be the context of the study, between India and Vietnam.

Last but not least, the results of this study also supported that of [11]. Nevertheless, PAEOUNOH are found to have only indirect associations with PURINT through the intervening role of BRIMAG instead of direct ones. How consumer experience the product; especially seeing, handling or using is also not included in this study.

\section{B. Limitations and Implications for Further Research}

Firstly, in this study, how consumers intend to buy a certain product or service is analyzed by only investigating factors of the package and brand image. However, this variable does not solely depend on these components. One suggestion is that this model should combine the perception of product quality [11] and the preference for a specific brand [43] as the mediation variables. As a result, a more comprehensive study on how consumer purchase intention is influenced can be achieved.

Another limitation is the total number of respondents of this research, which is 410 valid responses after collecting data. The whole process of data collection occurred in HCMC, Vietnam. Therefore, some modifications or changes in the 
results may exist or even these outcomes may not be true in other studies conducted in different backgrounds. Nevertheless, repeated studies with a larger sample size are encouraged to confirm these results and to make the generalization to the whole industry.

Furthermore, the major difficulty when conducting this research is in carefully watching over all respondents when doing the survey. We cannot be sure that all of the participants fully understand the whole content of the questionnaire because we could not explain every question in details for the respondents due to the lack of time. On the other hand, when misunderstanding some questions, they still continued to do the survey instead of asking. It results in some dishonest or inaccurate responses. Further studies should engage more time in the data collection process so they will receive less biased responses.

Last but not least, tea industry with the example of Phuc Long's packaged tea products, which is the scope of this study, is one of the limitations of this study. In particular, the criterion of the packaging process are completely distinctively for a wide range of products, so how consumers perceive the package of tea products and that of others is different. Therefore, the questionnaire design should be adjusted before being applied. Moreover, since Phuc Long is currently very popular in HCMC, some bias towards its products may be included when participants answer the questionnaire. It is recommended that further studies should analyze packaged tea products from other brands or even other kinds of products to test whether these results are the same or not.

\section{Recommendations for Tea Industry}

Based on the research's findings, recommendations for a good package of tea products are provided as follows.

(a) Appropriate and eye-catching pictures should be put on the package so that consumers can easily remember and differentiate this product with others. They can notice and identify immediately the package, and therefore, the purchase intention for that product will be higher.

(b) Although it is said that the color green represents for the tea products, when designing the package, tea brands should involve more colors in order to draw consumers' attention. Packaging colors which create good mood are encouraged, such as pink, orange, or yellow.

(c) Tea manufactures should design a good packaging shape which can protect the product inside when dispatching to target consumers. Besides, the shape should be easily notice from distance.

(d) The amount of product information printed on the package should be not too much and have to be clearly presented. Some common font styles such as Times New Roman or Arial should not be used because they can make consumers boring. Packaging designers can use other uncommon fonts but need to ensure that it is not too dense in writing.

(e) An easily handling, or opening and closing, or disposing package is a preferred choice. Nevertheless, most Vietnamese packaged tea products are still tied with a rubber band after opening in the first time. The tea's flavor and odor may be lost because of this action. Therefore, packaging designers can put tea leaves in the package under some following forms: (1) Slider, (2) EZ to Close, or (3) Press to Close (Fig. 2) [44]. These types provide consumers to easily re-close the product and to have ensure clean and safe storage.

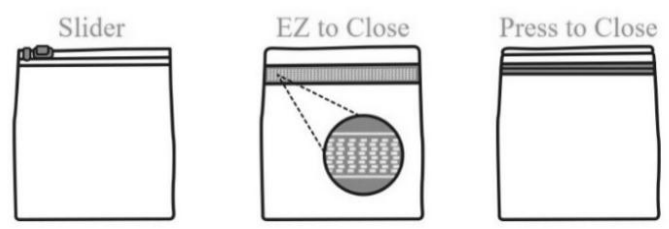

Fig. 2. Different forms of a product packaging.

Some guidelines for building a strong image are also presented.

(a) Tea brands need to identify who target consumers are, determine where the brand is in those minds, define what the value is, and develop what the key message for this group is.

(b) All types of promotion mix should be performed such as broadcast advertising, direct marketing, personal selling, or point of sale displays.

(c) For some tea brands especially Phuc Long Coffee and Tea House, which sells both take-away and packaged products, consumer service should also be taken into consideration. If more consumers purchase take-away products, the purchase intention for packaged items is also higher. Consumers will think of this brand more when they need to buy a gift for their seniors, or want to make a cup of tea at home. Therefore, a good consumer service is needed for these kinds of tea brands.

In short, those are the recommendations for the package of tea products and some suggestions in building a good brand image. Vietnamese tea brands should combine both two steps to increase consumer purchase intention.

\section{REFERENCES}

[1] P. G. Prendergast and L. Pitt, "Packaging, marketing, logistics and the environment: are there trade-offs?" International Journal of Physical Distribution \& Logistics Management, vol. 26, no. 6, pp. 60-72, 1996

[2] A. R. Raheem, P. Vishnu, and A. M. Ahmed, "Impact of product packaging on consumer's buying behavior," European Journal of Scientific Research, vol. 122, no. 2, pp. 125-134, 2014.

[3] B. Rundh, "The multi-faceted dimension of packaging: marketing logistic or marketing tool," British Food Journal, vol. 107, no. 9, pp. 670-684, 2005. Doi: 10.1108/00070700510615053.

[4] M. M. Deliya and B. J. Parmar, "Role of packaging on consumer buying behavior - Patan district," Global Journal of Management and Business Research, vol. 12, no. 10, 2012.

[5] M. F. Sial, A. Gulzar, N. Riaz, and B. Nawaz, "Impact of labeling and packaging on buying behavior of young consumers with mediating role of brand image," Interdisciplinary Journal of Contemporary Research in Business, vol. 3, no. 8, 2011.

[6] Thông tin về thị trường chè Việt Nam. (2007). [Online]. Available: http://agro.gov.vn/news/tID539_Thong-tin-ve-thi-truong-che-Viet-Na m.html

[7] P. Quyen. (2016). Phân tích thị trường cà phê Việt Nam năm 2016 [Online]. Available: https://maybanhang.net/2016/12/phan-tich-thi-truong-ca-phe-viet-na m-nam-2016/

[8] C. Nancarrow, L. T. Wright, and I. Brace, "Gaining competitive advantage from packaging and labelling in marketing communications," British Food Journal, vol. 100, no. 2, pp. 110-118, 1998.

[9] M. Lewis, "Understanding brands," Kogan Page, London, 1991.

[10] P. Silayoi and M. Speece, "Packaging and purchase decisions: an exploratory study on the impact of involvement level and time pressure," British Food Journal, vol. 106, no. 8, pp. 607-628, 2004. 
[11] G. R. Holmes and A. Paswan, "Consumer reaction to new package design," Journal of Product \& Brand Management, vol. 21, no. 2, pp. 109-116, 2012.

[12] J. Meyers-Levy and L. Peracchio, "Understanding the effects of colour: how the correspondence between available and required resources affects attitudes," Journal of Consumer Research, vol. 22, no. 2, pp. 121-139, 1995

[13] S. Singh, "Current research development: impact of color on marketing," Management Decision, vol. 44, no. 6, pp. 783-789, 2006.

[14] R. L. Underwood, N. M. Klein, and R. R. Burke, "Packaging communication: attentional effects of product imagery," Journal of Product \& Brand Management, vol. 10, no. 7, pp. 403-422, 2001.

[15] L. E. Wells, H. Farley, and G. A. Armstrong, "The importance of packaging design for own-label food brands," International Journal of Retail \& Distribution Management, vol. 35, no. 8, 2007.

[16] S. Jafari, M. S. nia, M. Salehi, and R. Zahmatkesh, "Influence of package on consumer behavior," Arabian Journal of Business and Management Review (OMAN Chapter), vol. 2, no. 6, pp. 65-71, 2013.

[17] M. E. H. Creusen and J. P. L. Schoormans, "The different roles of product appearance in consumer choice," The Journal of Product Innovations Management, vol. 22, pp. 63-81, 2005.

[18] C. H. Noble and M. Kumar, "Exploring the appeal of product design: a grounded, value-based model of key design elements and relationships," Journal of Product Innovation Management, vol. 27, no. 5 , pp. $640-657,2010$.

[19] B. Wansink, "Can package size accelerate usage volume?" Journal of Marketing, vol. 60, no. 3, pp. 1-14, 1996.

[20] V. S. Folkes, I. M. Martin, and K. Gupta, "When to say when: effects of supply on usage," Journal of Consumer Research, vol. 20, no. 3, pp. 467-77, 1993.

[21] A. Ford, C. Moodie, and G. Hastings, "The role of packaging for consumer products: understanding the move towards 'plain' tobacco packaging," Addiction Research \& Theory, vol. 20, no. 4, pp. 339-347, 2012.

[22] B. Ranjbarian, S. Mahmoodi, and A. Shahin, "Packaging elements and consumer buying decisions," International Journal of Business Innovation and Research, vol. 4, no. 4, pp. 376, 2010

[23] S. Farooq, S. Habib, and S. Aslam, "Influence of product packaging on consumer purchase intentions," International Journal of Economics, Commerce and Management, vol. 3, no. 12, 2015.

[24] H. Singh, "Relationship between packaging and consumers buying behavior," International Journal for Innovative Research in Multidisciplinary Field, vol. 2, no. 5, 2016.

[25] R. C. Lal, F. Yambrach, and L. McProud, "Consumer perceptions towards package designs: a cross cultural study," Journal of Applied Packaging Research, vol. 7 no. 2, 2015.

[26] K. Venter, D. V. Merwe, H. D. Beer, E. Kempen, and M. Bosman, "Consumers' perceptions of food packaging: an exploratory investigation in Potchefstroom, South Africa," International Journal of Consumer Studies, vol. 35, pp. 273-281, 2011.

[27] F. D. Davis, R. P. Bagozzi, and P. R. Warshaw, "User acceptance of computer technology: a comparison of two theoretical models," Management Science, vol. 35, no. 8, 1989.

[28] K. L. Paswan "Conceptualizing, measuring, and managing customer-based brand equity," Journal of Marketing, vol. 57, no. 1, pp. 1-22, 1993.

[29] D. Roy and S. Banerjee, "CARE-ing strategy for integration of brand identity with brand image," International Journal of Commerce and Management, vol. 17, no. 1/2, pp. 140-148, 2008.

[30] D. A. Aaker, "Managing brand equity," New York: The Free Press, 1991.

[31] S. Nandan, "An exploration of the brand identity-brand image linkage: a communications perspective," Brand Management, vol. 12, no. 4, pp. 264-278, 2005.
[32] M. H. Hsieh, S. L. Pan, and R. Setiono, "Product-, corporate-, an country-image dimensions and purchase behavior: A multicountry analysis," Journal of the Academy of Marketing Science, vol. 32, no. 3, pp. 251-270, 2004.

[33] M. Gabbott and G. Hogg, "Consumers and services," Chichester: John Wiley \& Sons, 1998

[34] M. Fishbein and I. Ajzen, "Belief, attitude, intention, and behavior: an introduction to theory and research, reading," MA: Addison <Wesley, 1975.

[35] S. Bhakar, S. Bhakar, and A. Dubey, "Analysis of the factors affecting customers purchase intention: the mediating role of customer knowledge and perceived value," Advances in Social Sciences Research Journal, vol. 2, no. 1, 2015.

[36] B. Kupiec and B. Revell, "Measuring consumer quality judgments," British Food Journal, vol. 103, no. 1, pp. 7-22, 2001.

[37] D. Funk and N. O. Ndubisi, "Color and product choice: a study of gender roles," Management Research News, vol. 29, no. 1/2, pp. 41-52, 2006.

[38] D. George and P. Mallery, SPSS for windows step by step: a simple guide and reference. 11.0 update, 4th ed. Boston: Allyn \& Bacon, 2003.

[39] J. Pallant, SPSS Survival Manual: A Step by Step Guide to Data Analysis Using SPSS, 12th ed., Maidenhead, Berkshire: Open University Press, 2005

[40] M. S. Bartlett, "A note on multiplying factors for various chi-squared approximations," Journal of the Royal Statistical Society, vol. 16, pp 296-298, 1954.

[41] J. K. Preacher and A. F. Hayes, "Asymptotic and resampling strategies for assessing and comparing indirect effects in multiple mediator model," Behavior Research Methods, vol. 40, no. 3, pp. 879-891, 2008.

[42] D. De Vaus, "Surveys in social research," Psychology Press, NSW, Australia, 2002.

[43] E. S.T. Wang, "The influence of visual packaging design on perceived food product quality, value, and brand preference," International Journal of Retail \& Distribution Management, vol. 41, no. 10, pp. 805-816, 2013.

[44] Product specifications. [Online]. Available: http://www.peelplastics.com/product-details.php?product=fold-over-b ottom-hook

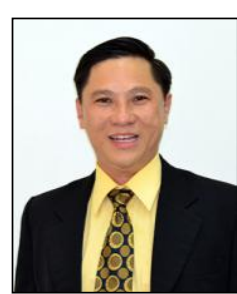

Mai Ngoc Khuong is a lecturer and researcher of School of Business Administration, International University, Vietnam National University, Ho Chi Minh City. He has a bachelor degree in tourism and hospitality management, master of science degree in leisure, tourism and environment at Wageningen University, The Netherlands, and $\mathrm{PhD}$ degree in development management at School of Public Administration of the National Institute of Development Administration (NIDA), Bangkok, Thailand.

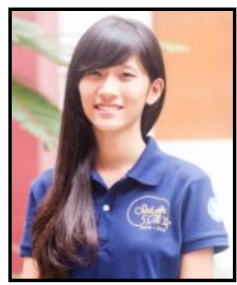

Nguyen Thi Huyen Tran is a student of School of Business Administration, International University, Vietnam National University, Ho Chi Minh City, Vietnam, who has completed her Bachelor degree of Business Administration. She is specialized in Marketing and interested in Customer behaviors, Leadership, and Entrepreneurship. 